\title{
AN INVESTIGATION THE MAIN INTERNAL BRAND CRISIS ANTECEDENTS
}

\author{
Bich Ngoc DO ${ }^{1}$, Tuan Phong NHAM ${ }^{2}$, Tuyet-Mai NGUYEN ${ }^{3}$ \\ ${ }^{1}$ Department of Social Sciences, Economic and Management, \\ International School - Vietnam National University, Hanoi, Vietnam \\ ${ }^{2}$ VNU University of Economics and Business, Hanoi, Vietnam \\ ${ }^{3}$ Department of Marketing, Griffith Business School, Griffith University Australia, \\ Queensland, Australia and Department of Economic Information System and E-commerce, \\ Thuongmai University, Hanoi, Vietnam \\ E-mails: ${ }^{1}$ bichdn@isvnu.vn (corresponding author); ${ }^{2}$ tuannp@vnu.edu.vn; \\ ${ }^{3}$ mai.nguyenthituyet@griffithuni.edu.au
}

Received 26 November 2018, accepted 18 February 2019

\begin{abstract}
To enrich literature of brand crisis causes regards internal perspective, this paper investigates internal brand shortage as crisis antecedents provoking brand fire consequently. Phenomenological approach is adopted using in-depth interviews, keynote seminar and validating by case studies analysis, internal brand crises antecedents were explored based on insights taken from experts in marketing and branding industry. Drafting from the phenomenological research, there are six problems leading to crisis found as follows: lack of human-centred strategy, lack of crisis prevention, lack of market understanding, lack of leadership and management skill, lack of innovation, and lack of quality assurance. These internal antecedents which accumulate to both performance-related and value-related brand crisis. This paper can have explicit implications for marketer, branders and managers, understanding these drivers and its occurrence, business managers are able to scan and analyses crisis situation faster to form timely response to crisis.
\end{abstract}

Keywords: brand crisis antecedents, brand crisis cause, brand crisis drivers, crisis prevention, performance-related crisis, valuerelated crisis, and internal perspective approach.

JEL Classification: M0.

\section{Introduction}

Building brand is sophisticated and tough for any organisations. To cope with these challenges, branding process requires a comprehensive understanding - well-blended information from external market and organizational capabilities (López-Cabarcos et al. 2015). Yet, even firms seem to be fully understood their business environment, it is then vital to investigate why brands still continue to communicate, implement erroneous activities and generate brand crises consequently.

Social media, a part of the business nowadays, has brought both opportunities and challenges for firms in either building or destroying brand reputation. Dating back the 2000s, brands used to communicate and solve scandals mainly on mass media (Jahng and Hong 2017) such as offline channels. Web 3.0 has changed consumer perception into fragmentation (Euromonitor 2018) and fragile (Zou and Li 2016). Due to limited brand consciousness (McKinsey 2012) and heavy reliance on social interactions in all forms - virtual and physical (Paulwels et al. 2013), consumers' attitude and perceptions are re-shaped. In other words, it partly altered by external variables such as new information, new cultures or meanings especially brand's information (Peter and Olson 2010, Fan et al. 2012, Augusto and Torres 2018). It is evident from recent cases that brand crisis has occurred with an increased frequency throughout the past few years (Do 2016). Considering merely 2017 and 2018, there is already a significant number of big brands such

Copyright (C) 2019 The Authors. Published by VGTU Press.

This is an Open Access article distributed under the terms of the Creative Commons Attribution License (http://creativecommons.org/licenses/by/4.0/), which permits unrestricted use, distribution, and reproduction in any medium, provided the original author and source are credited.. 
as Facebook (Forbes 2018, Marketingweek 2018), United Airlines (PRweek 2017, Business Insider 2018), Pepsi US (PRweek 2017) which found themselves in deep water of brand crisis. Hence, it can be said that brand crisis starts when negative information starts to spread on media platforms.

During crisis time, stakeholders expect instant actions and tend to search for related-information such as causes then consequently form adjusted brand attitude towards consumption (Jung and Sung 2008, Ip et al. 2018). Currently, considered a sensitive topic, brand crises increasingly and continuously occur and are far more complex to handle (Do 2016) especially in Asia.

Current brand crisis management is divided into three phases: pre-crisis, crisis management, post-crisis management (Bundy et al. 2017). Regarding the pre-crisis phase, two perspectives were identified which are internal and external. Prior researchers explored brand crisis causes as guidelines for branders and marketers to assess their crisis situation namely Tyagi (2006), Coombs (2007), Greyser (2009), Bundy and Pfarrer (2015) and Hasen et al. (2018), Griffith et al. (2018). Those studies emphasized detecting situational characteristics of crises that are perceived by external stakeholders for example product failures or communication failures (Bundy et al. 2017) while the internal perspective concentrates on organizational internal crisis preparedness. However, in this respect the internal perspective is scarce, particularly on how and which internal factors cause brand problems leading to crisis afterwards (Bundy et al. 2017, Forbes 2018). According to recent review of Forbes (2018), brand crises are outcomes of one or sequential mistakes from organizations internally. Without fully acknowledging the deep root of crisis problems, it is impossible to completely combat issues; all solutions can only be temporary. Considering the lack of attention on brand crisis antecedents, this paper is conducted to explore internal reasons leading to brand crisis and form a research question as follow: What are key internal drivers leading to brand crisis?

\section{Literature review}

\subsection{Brand crisis}

Brand crisis is an unpredictable and unexpected situation that challenges organizational health (Coombs 2015), stability and performance (Rea et al. 2014) at any time in a business life cycle. It can be said that brand crisis is similar to a disease pushing organizational activities and brand assets into a chaos, and threatening future growth. Previous researchers categorized brand crisis into two main types: performance-related crisis and value-related crisis (Wang 2016). The former indicates the inability to fulfil the brand's promises regarding product quality, product harm or performance standard that failed to meet consumers' expectation. The latter does not literally relate with tangible products; however, it involves moral/ethical problems surrounding brand perceived value of stakeholders (Dutta and Pullig 2011).

Social media is non-sleep platform which enables people participation and experiences/opinions sharing. Without any boundaries and interferences of media agents, organizational crisis on social media continuously increased since 2011 (Owyang 2011, Forbes 2018). According to a recent report by Statista (2018), a third of world population is committed to this virtual society. On these social media platforms, crisis news can be shared and re-shared millions of times (Jia et al. 2017) in a few minutes; reality crisis cases in 2017 and 2018 such as Starbuck US, Lancome Hongkong or Watson Malaysia have witnessed the uncontrollable spread of negative news. Currently, a small error in advertising content, an offensive promotional idea, a wrong reply on Internet sites can create unintended public opinions and quickly generate brand troubles (Labrecque et al. 2013, Hewett et al. 2016). Therefore, building brand requires emotional attachment with audiences through different approaches (Gobé 2009); yet, those emotional connections between brand and stakeholders become as sensitive as human sense and are more complex to handle when crisis occurs.

Table 1. Crisis causes (source: authors' collection)

\begin{tabular}{|c|l|l|}
\hline No & \multicolumn{1}{|c|}{ Crisis causes } & \multicolumn{1}{c|}{ Explanation } \\
\hline 1 & Product failure & $\begin{array}{l}\text { Crisis happens when product might not meet consumers' expectation and their perception or it } \\
\text { was found to be dangerous and damage human mechanics (Tyagi 2006, Laufer et al. 2017). }\end{array}$ \\
\hline 2 & $\begin{array}{l}\text { Communication } \\
\text { strategies failure }\end{array}$ & $\begin{array}{l}\text { Communication failure (Ma and Zhan 2016) appears when brand un-succeed in delivering } \\
\text { supposed message to consumers such as mis-understanding or falling into a culture trap. }\end{array}$ \\
\hline 3 & Executive misbehavior & $\begin{array}{l}\text { Brand image might be under fire if executive manager performs any misbehavior such as } \\
\text { violation, harassment, and bribes (Greyser 2009, Harvard Business Review 2016). }\end{array}$ \\
\hline 4 & $\begin{array}{l}\text { Corporate misbehavior } \\
\text { Ethical/moral failure) }\end{array}$ & $\begin{array}{l}\text { Crisis happens when organizations perform unethical behavior and ignores public opinions such } \\
\text { as inequality, lack of transparency, environmental damages, discrimination (Crane 2001, Fan } \\
\text { 2005, Griffith et al. 2018) }\end{array}$ \\
\hline 5 & $\begin{array}{l}\text { Spokesperson/brand } \\
\text { ambassador misbehavior }\end{array}$ & $\begin{array}{l}\text { A single controversial quote or misbehavior of spokesperson can damage brand identity and } \\
\text { generate brand crisis (Salvador et al. 2018) }\end{array}$ \\
\hline
\end{tabular}




\subsection{Internal crisis causes}

Suggested in many papers, crisis communication requires a deep understanding about crisis origins to design suitable actions (Coombs 2007). Prior studies mentioned various of crisis causes (Greyser 2009, Tyagi 2006, Fan 2005, Crane 2001). Synthesizing from several academic research, Table 1 illustrates five popular causes/issues leading to brand crisis.

Those crisis origins are classified according to different causes of corporate brand crises that can be perceived by external stakeholders.

\subsection{Brand crisis consequences}

Once organizations face brand crisis, brands would struggle to manage huge damages (Claeys and Cauberger 2014) from tangible to intangible. Synthesizing from previous literature, there are four negative consequences resulting from brand crisis: stakeholders' confidence, brand reputation, brand equity, and business performance.

Firstly, brand rumours spread like uncontrollable wildfire because of Web 3.0. For external stakeholders, it is adamantine to critically evaluate the credibility and form fair decisions (Chiou et al. 2013) during crisis. Severity of negative information triggers audiences' fear and confidence towards products and brands (Johar et al. 2010, Bilgihan et al. 2016). For internal stakeholders, they might be more sensitive and experience crisis negative effects earlier than external ones (Snoeijiers and Poels 2018). Thereby, this phenomenon also explains why stock prices would witness a tough period when crisis occurs.

Secondly, brand reputation is a firm's intangible value (Coombs 2007). It is developed through stakeholders' evaluation and perception with regards to how famous a brand is. As mentioned in the prior paragraph, crisis harms audience's emotion and logical thinking; all burdensome news/ rumours from external environment can indirectly destroy brand reputation (Xiao et al. 2018).

Thirdly, brand equity is defined as total assets less total liabilities linked to brand's name and symbol that adds value to firms (Aaker 2010, Huang and Sarigöllü 2012) including brand awareness, brand loyalty, perceived quality and brand associations. A study of Dawar and Lei (2009) explored a correlation between brand equity and brand crisis. According to Jeon and Beack (2016) and Hsu and Lawrence (2016), brand equity and all relative elements were found to be damaged. From actual crisis cases such as Lancom Hongkong or Watson Malaysia, many brands under crisis lose their loyal customers and increase boycott audience as a result. Thus, brand crisis is a risk factor for building and maintaining brand equity.

Last but not least, business results might witness tough period when brand crisis hits. Prior scholars agreed that brand crisis has negative effects on market share, stock prices, and other assets attached with brands (Rea et al. 2014). Consumers, under influences of negative publicity tend to boycott relevant products and services attached with that brand name (Braunsberger and Buckler, 2011, Griffith et al. 2018). In the majority real cases, stock price immediately plummet after crisis news released such as Tan Hiep Phat Vietnam, Lancome Hongkong, Watson Malaysia. Therefore, business results, or sale volume precisely, are substantially on decline during crisis period as a result of brand boycott.

\subsection{Literature gaps}

From reviewing relevant papers related to brand crisis, there are some literature gaps found. Brand crisis and its impacts on stakeholders/business health have been defined in various papers mentioned in prior paragraphs. In order to respond in a timely manner, managers and marketers must critically identify and understand all causes leading to a crisis (Coombs 2007, Coombs and Holladay 2009). Most studies of brand crisis causes have been primarily carried out to explore reasons leading to brand crisis (Tyagi 2006, Coombs 2007, Greyser 2009, Bundy and Pfarrer 2015, Hansen et al. 2018, Griffith et al. 2018). According to Forbes (2018), brand crisis causes are likely to be outcomes of singular or sequential mistakes internally that somehow cannot be perceived by external actors and agents. Yet, there is little attention on researching crisis antecedents' especially internal drivers and its frequent occurrence to provide early warning for business and organizations (Bundy et al. 2016, Griffith et al. 2018). Considering this lack of attention, this research is conducted through a qualitative method as keynote seminars, experts interview and case studies analysis to uncover insights of brand mistakes from internal perspective to explore antecedents leading to brand crisis.

\section{Research methodology}

This study adopts qualitative research - experts interview, key note speaker and case studies analysis to identify most frequent drivers leading to brand crisis. Firstly, according to Thomas and Harden (2008) descriptive methods are appropriate to help researchers classify categories/ factors for further quantitative study. Secondly, qualitative methods can provide detailed and in-depth information (Silverman 2016). Therefore, qualitative approach is suitable to use in this research.

\section{Expert interviews}

In the first phase, data collection and analysis follow guidelines of an interpretive research. Authors adopted a purposive and convenience sampling (Silverman 2016); all interview participants were carefully selected based on 
their profile and experience in branding and marketing industry. Professional participants should be Brand consultant, Marketing Manager, Creative Marketing Manager, Business owner or Business Analyst (Choi and Lin 2009). Experts in such position hold both creative and strategic perspectives and can provide insights regarding brand crisis justification. The interviews primarily were conducted in Vietnam. Some experts are interviewed face-to-face in both Hanoi and Hochiminh City, whereas other experts living in other countries such as Singapore and the United Kingdom were interviewed via video skype.

Collected data was varied and depended on their perceptions and experiences in this industry. This information need to be organized systematically; according to Mills (2003) and Gibbs (2007), the collected data can best be treated under four stages:

(1) Creating storyline from interview

(2) Coding data into systematic categories such as words, themes, and concepts. In this study, researchers will code data according to brand crisis causes and its effects.

(3) Identify key insights of collected data by number of appearances in each storyline.

(4) Illustrate codes for each element using diverse perspectives.

\section{Guest lecture and key note speakers}

Researchers identified this source which was invaluable to identify possible antecedents to brand crisis. During 4 months, researchers attended 4 seminars and guest lectures at Brunel University London to take note of key ideas for research questions.

\section{Case studies analysis}

In this study, case studies have been increasingly used as a research tool to explore holistic and distinctive components of empirical studies such as individual characteristics, bi-directional relationships, influences of stimuli in the society (Yin 2014). By using coded results from interview and key-note speaker storyline, authors might examine that appear most frequently to answer research questions following idea of Silverman (2006).

Yet, this type of research has an implicit (Yin 2014), researchers need to avoid situation that collected data did not address initial intention. Thus, to ensure the validity and reliability, it is essential to choose multiple sources of evidence (Neuman and Kreuger 2003). From these requirements, 16 case studies were chosen from diverse backgrounds and industries to conduct analysis. Case studies are chosen from various industries to ensure validity and reliability of this

Table 2. Interview coding results - Brand crisis drivers (source: authors' coding results)

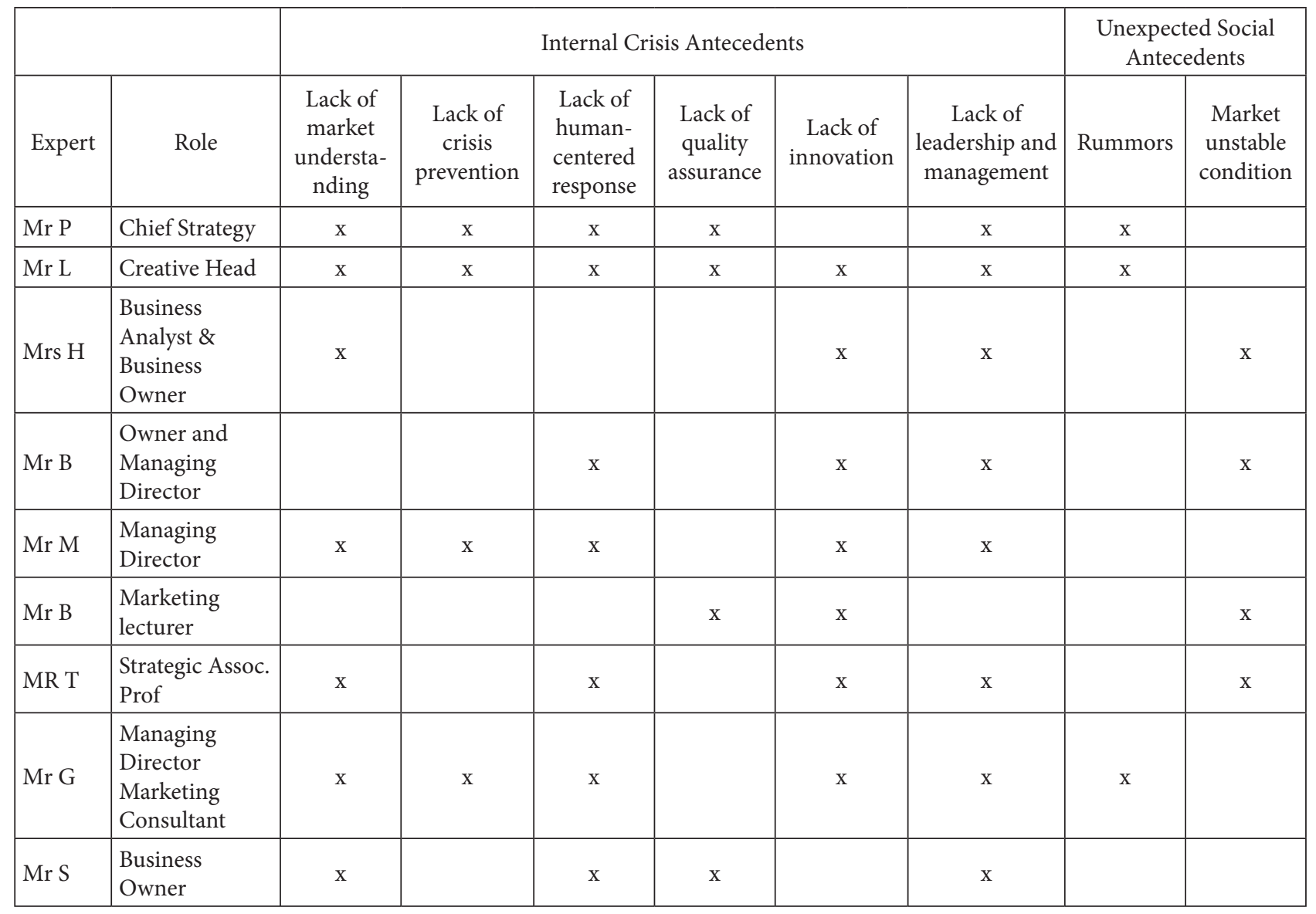


technique (Appendix). Key insights are antecedents leading to brand crisis that taken from various sources of practical analysis such as IDEO report, PRweek, Campaign premium analysis combining with academic journals such as Journal of Marketing.

\section{Data analysis results and discussion}

\subsection{Experts interviews}

Regards crisis drivers, interviewed experts mentioned and explained various internal and external drivers leading to brand crisis based on their experience. Table 2 illustrates key crisis drivers taken from longitudinal interviews.

From Table 4, there are total 8 crisis drivers identified from the interviews, in which 6 are within the organizations and 2 are from the external environment:

\section{(1) Lack of crisis prevention strategy:}

Majority of experts (eight out of nine) claimed that brands especially Asian brands seem to be inactive in solving brand crises. Current brands' solution for brand crisis has been staying "silent". Silence refers to situation when brands perform late and passive response in dealing with crisis spread (Bradley 2018). This passive state is caused by lack of crisis prevention strategy (Bundy et al. 2016).

"Late response may exasperate stakeholders' negative attitude and perceptions towards brand's mistakes" (Mr. M - Managing Director)

"Crisis prevention strategy is a prerequisite for firms to handle brand crisis in a timely manner, it is also a factor that worsens brand mistakes and form huge crisis afterwards" (Mr. L - Creative Director)

In meta-analysis of Arendt et al. (2017), those inactive strategies such as silence, innocence or shift of the blame are the least successful factors as consumers easily search for information on the Internet. Silence as a crisis action will only work if the firm has a strong capital base to survive, to control all media agents and to invest in massive communication when scandals are faded. This idea is compatible with Cleeren's study (2015) on product-harm crisis. Hence, firms should be aware that lack of crisis prevention strategy being a driver to form or worsen brand crisis.

(2) Lack of human-centered design communication strategy:

Human-centered design is popular in the technical sector. Human-centered design is first applicable for design industry since 2003 (Kuniavsky 2003). Yet, in recent years, it attracted attention from practical experts, human-centered design is not only about customers, it is the inherence of stakeholders' interests, ethical manner, social responsibilities and public affairs in communication design. The importance of human-centered in communication first is addressed in paper of Giacomin (2014) and then Putnam et al. (2016). As such, the terms such as "lack of consciences", "lack of environmental protection", "lack of honesty" or "lack of ethics \& morality" tend to refer to "the lack of human-centred" strategy (IDEO 2015).

From the interview, seven out of nine experts agreed that these mistakes easily lead to sequential brand crisis causes such as lack of business ethics and moral in marketing communication.

"Lack of humanity and social concerns are not placed at the core of communication strategy" (Mr. T - Owner and Managing Director).

Specifically, branding strategy aims to build a person and to create human connections between brands and their users.

"Brand and users relationships are sensitive and fragile owing to brands' mistake" (Mr. G - Brand Manager)

These positive connections are able to leverage brand value and to sustain brand love in the long-term (Putnam et al. 2016).

This finding is in line with idea of Giacomin (2014), business catastrophic failures come from organizational failure to fulfil users' tangible and intangible desires. Those human-centered factors, from micro issues such as ethical concerns to more macro issues such as environmental concerns, are positively influenced by stakeholders' perception and buying intention (Marynissen et al. 2013, Zou and Li 2016, Chun 2016). Branding is sensitive (Malone and Fiske 2014), human value is central in generating dialogue between brands and audiences; thus, lacking of humancentred communication strategy is considered one of internal brand crisis drivers.

\section{(3) Lack of market understanding:}

This driver refers to insufficient information regarding customer preferences, customer response habits, macro and microenvironment in marketing research (Kotler et al. 2018, Mr. M and Mrs. L (keynote speaker). From the strategic point of view:

"Market understanding is a crucial component for successful brand strategy and implementation" (Mr. P - Chief Strategy).

"Without market acknowledgement, firms might fall to the trap of product failure, communication failure and other types of ethical failures when dealing with culture for instance" (Mr T - Strategic Expert).

The real crisis cases such as Watson Malaysia (2017) or Lancome Hongkong (2016) were evidences to prove this factor as a brand crisis driver in action.

\section{(4) Lack of innovation:}

Innovation broadly contributes to sustaining brand's health and retaining competitive advantages in the digital proliferation 4.0. It refers to adopting new technology advancements in business operation and marketing communication to narrow negative effects of brand crisis and prevent future crisis incidents (Anning-Dorson 2018). 
According to coding results, innovation might contract operation accidents and mistakes happened during the production process.

Secondly, in case of under innovation and innovation failure, it would trigger consumers' expectations regarding product and service performance (Mrs. $\mathrm{H}$ - Business Analyst). These mistakes disappoint users emotionally, which caused performance-related brand crisis (Mr. M and Mr. B - Managing Director). Florea (2015) explored that this factor has a major negative impact on audiences' perception of small firms with low brand equity, but only have a minor impact on firms achieving high brand equity. Perhaps, this distinct finding is owing to research context. This research is conducted according to personal experiences from diverse background whereas Florea conducted in hospital sector. IDEO (2015) and Roll (2015) also emphasized innovation as a key to sustain brand in digital age 4.0.

In the seminar of Mrs L (Business Partner), she also supported the interviewees' idea regarding the risk of underinnovation and role of design thinking in branding generally and brand crisis particularly.

"Under-innovation might lead to product failure if firms do not adopt sufficient technology to assure the manufacturing process or lead to communication failure if firms do not adopt advanced listening tools to understand the market" (Mr. S and Mrs. H - Business Owner).

Especially, under-innovation in communication might lead to lack of market understanding that refers to the major trap of brand communication crisis (Mrs. $\mathrm{H}$ - Business Analyst).

\section{(5) Lack of leadership and management skill:}

The fifth finding refers to management and leadership weaknesses that result in late response and other humanrelated misbehaviour. This driver received absolute support from experts as a major antecedent for sequential mistakes leading to brand crisis. There are three dangers related to this driver as follow:

\section{Cross-functional management}

With the transformation in global human resources, both global and local firms need to work in cultural diversity context (Mr. G - Brand Managing Director). Proven by recent brand crises cases such as Starbuck, KFC, brand performance is directly influenced by organizational culture management and human management. Previous research follows two main streams: external perspective and internal perspective (Bundy et al. 2017). This finding can be categorized as internal perspective which recognizes organizational culture management as an additional driver making brand crises more likely.

\section{Silos effect}

Silo is a metaphor for the failure of motivation, working desires and communication internally. According to a majority of experts, silo effect is likely to dissatisfy and cause negative emotion for internal stakeholders. It also triggers misbehaviour or mistakes especially when dealing with consumers such as case of Starbuck or Domino. As found in other studies of human resources management, it refers to lack support across functional department (Torrington et al. 2017), which results in internal network fragility.

\section{Brand consistency}

Ideal brand building is consistent identity and personality that strengthen brand positioning (Mr.T - Strategic professor). However, in fact, after running business for longperiod, brands unintentionally fall into the trap of "blur positioning". As such, audiences unconsciously form inconsistent knowledge towards brand position. Some experts used the case of Burberry UK as an example to illustrate that failure in retaining consistent brand positioning might result in brand crisis.

\section{(6) Lack of quality assurance:}

The most prevailing trap of all products and services is the product quality trap according to four out of nine experts. It refers to failures in maintaining product quality standard (features, functions, and operations). Experts defined three factors that influence product quality assurance: design failure, issue in manufacturing process, and raw material resources. When a product has an issue regarding quality and performance, users are likely to stop buying and spread negative rumours on virtual platforms (Mr. L - Creative Head and Mr. B - Marketing Lecture). This is when brand crisis starts and spillovers.

Apart from internal drivers, experts further mentioned two external crisis drivers: rumours and unstable market condition. Nonetheless, this paper concentrates on exploring internal brand crisis drivers; hence, these two factors are eliminated from the antecedents list.

\subsection{Keynote seminar}

Taking part in four seminars, brand crisis information is summarized into key opinions of four experts in branding crisis drivers (Table 3 ).

Second stage of key-note speaker analysis is to examine the occurrence of all mentioned crisis drivers following qualitative research coding guideline.

From Table 4, four out of six internal antecedents taken from in-depth expert interviews were matched with keynote speaker ideas. Those antecedents can transform into continuous problem(s), thus, the businesses might be faced with several extended crises that could pollute the purity of the brands. 
Table 3. Keynote speakers' opinions (source: authors' coding collection)

\begin{tabular}{|l|l|}
\hline \multicolumn{1}{|c|}{ Position/Field } & \multicolumn{1}{c|}{ Main Opinions } \\
\hline Business Partner & $\begin{array}{l}\text { The core of failure is due to the shallow understanding of market changes, the human cultures and the } \\
\text { consumers of tomorrow. Business should intentionally invest their efforts in the future of qualitative research } \\
\text { about human communication in order to cope with changes and identify the shape of expanding culture. }\end{array}$ \\
\hline $\begin{array}{l}\text { Project Lead, } \\
\text { Product and } \\
\text { Service Design }\end{array}$ & $\begin{array}{l}\text { Most organizations are facing the problems from social responsibilities and environmental issues. Those } \\
\text { factors come from lacking market understanding and under-estimating human-value in doing business. } \\
\text { interfere with the ways that business behaves. As the awareness of social and environmental issues is } \\
\text { increasing, he suggested the brands to innovate, design and develop products and services that offer better } \\
\text { social values. }\end{array}$ \\
\hline Product manager & $\begin{array}{l}\text { - Lack of connections and relationships among internal stakeholder might } \\
\text { - Leverage brand crisis seriousness. In case product harm crisis, designer and operation executives can } \\
\text { provide solid information to help marketer communicate to external stakeholders. This collaboration requires } \\
\text { intensive leadership and management effort from board team. }\end{array}$ \\
\hline $\begin{array}{l}\text { Director of } \\
\text { Human Centered } \\
\text { Design Institute }\end{array}$ & $\begin{array}{l}\text { - Failure to provide innovative solution to current consumer problems can lead to business failure and brand } \\
\text { crisis }\end{array}$ \\
\hline
\end{tabular}

Table 4. Key-note seminar coding results (source: authors' collection)

\begin{tabular}{|l|l|c|c|c|c|c|c|}
\hline $\begin{array}{c}\text { Academic } \\
\text { experts }\end{array}$ & Position & $\begin{array}{c}\text { Lack of market } \\
\text { understanding }\end{array}$ & $\begin{array}{c}\text { Lack of crisis } \\
\text { prevention }\end{array}$ & $\begin{array}{c}\text { Lack of } \\
\text { human-centred } \\
\text { response }\end{array}$ & $\begin{array}{c}\text { Lack of } \\
\text { quality } \\
\text { assurance }\end{array}$ & $\begin{array}{c}\text { Lack of } \\
\text { innovation }\end{array}$ & $\begin{array}{c}\text { Lack of leadership } \\
\text { and management }\end{array}$ \\
\hline Mrs. L & Business Partner & $\mathrm{X}$ & & $\mathrm{X}$ & $\mathrm{X}$ & \\
\hline Mr. L & $\begin{array}{l}\text { Project Lead, } \\
\text { Product and } \\
\text { Service Design }\end{array}$ & $\mathrm{X}$ & $\mathrm{X}$ & & & & \\
\hline $\mathrm{Mr}$ T & $\begin{array}{l}\text { Product } \\
\text { Manager }\end{array}$ & $\begin{array}{l}\text { Academic } \\
\text { Professor in } \\
\text { Human Centred } \\
\text { Design }\end{array}$ & & & & & $\mathrm{X}$ \\
\hline $\mathrm{Mr}$ G
\end{tabular}

Synthesizing from both interviews and key-note speeches, six founded factors driving brand to crisis would be used to analyse case studies in the next stage and to validate the generalization of those factors in real brand crisis cases.

\subsection{Case studies analysis}

Summaries of case studies analysis results are illustrated in Figure 1.

From case studies analysis results, it is shown that all six antecedents founded from prior two phases are part of the crisis cases.

Interestingly, four most frequently repeated brand crisis antecedents in 16 case studies are: lack of crisis prevention, lack of human-centred strategy, lack of leadership and management, and lack of market understanding. These drivers are founded to cause both value-related and performancerelated crisis (details of case studies analysis can be founded in Appendix 1). The last two drivers, lack of innovation and lacking of quality insurance, which were only repeated 3-4 times, are likely to cause performance-related crises rather than value-related crises.

\section{Conclusions, implications and future research}

This exploratory study examines the internal drivers/antecedents leading to brand crisis. Adopting qualitative research, this paper explored some notable findings which are elaborated below.

In order to respond in a timely manner, brand crisis situation analysis should be observed and identified from both internal and external attributes. This study contributes to a deeper understanding of which internal drivers lead to brand crisis. Six different antecedents leading to brand crisis based on internal perspective were founded. They are (1) lack of human-centred strategy, (2) lack of leadership and management skill, (3) lack of crisis prevention, (4) lack of market understanding, (5) lack of innovation, and (6) lack of quality assurance. These antecedents are not accessible by external forces. These six drivers received remarkable 


\begin{tabular}{|c|c|c|c|c|c|c|c|c|c|c|c|c|c|c|c|c|c|}
\hline \multicolumn{2}{|c|}{ CRISIS ANTECEDENTS } & SHEL & soorus & $\begin{array}{c}\text { Domiso } \\
\text { us }\end{array}$ & $\begin{array}{c}\text { THomas } \\
\text { cook-CKK }\end{array}$ & 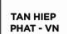 & 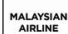 & $\begin{array}{l}\text { LAMCOME } \\
\text { HNOG G }\end{array}$ & 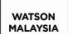 & LOREAL & PepsiUs & 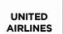 & нем & Tescouk & wires & FacBooo & KFC UK \\
\hline \multirow{2}{*}{$\begin{array}{l}\text { LACK OF } \\
\text { MARET } \\
\text { UNDERSTANDING }\end{array}$} & CONSUMER & & & & & & & & & & & & & & & & \\
\hline & ENVIRONMENT (CULTURE, POLTTICS) & & & & & & & & & & & & & & & & \\
\hline \multirow{2}{*}{$\begin{array}{l}\text { LACK OF } \\
\text { CRISIS } \\
\text { PREVENTION }\end{array}$} & LACK OF CRIIIS RESPONSE SPEED & & & & & & & & & & & & & & & & \\
\hline & PASSIVE IN CRISIS RESPONSEE & & & & & & & & & & & & & & & & \\
\hline \multirow{3}{*}{$\begin{array}{l}\text { LACK OF } \\
\text { HUMAN-CENTERED } \\
\text { RESPONSE }\end{array}$} & ETHICAL AND MORAL MANNER & & & & & & & & & & & & & & & & \\
\hline & RECALL TO PAST CRISIS & & & & & & & & & & & & & & & & \\
\hline & TRANSPARENCY AND RESPONSBILLTY & & & & & & & & & & & & & & & & \\
\hline \multicolumn{18}{|l|}{$\begin{array}{l}\text { LACK OF QUALITY } \\
\text { ASSURANCE }\end{array}$} \\
\hline \multicolumn{18}{|l|}{ LACK OF INNOVATION } \\
\hline \multirow{2}{*}{$\begin{array}{l}\text { LACK OF } \\
\text { LEADEREPSIP } \\
\text { \&MANAGEMENT }\end{array}$} & 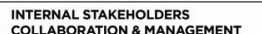 & & & & & & & & & & & & & & & & \\
\hline & $\begin{array}{l}\text { EXTERNAL STAKEHOLDERS } \\
\text { COLLABORAOION \& MANGEMENT }\end{array}$ & & & & & & & & & & & & & & & & \\
\hline
\end{tabular}

Figure 1. Case studies coding results (source: authors' coding results)

emphasis from experts and key-note speakers as main determinants intermittently cause brand crisis.

Firstly, business management is full of expectancy; however, crisis prevention is pre-crisis phase that might estimate and cover hidden dangers from internal such as innovation, quality control and human-centred respond. Companies need to scan internally continuously using crisis prevention team which consist of cross-functional key person. This team must have brander- who understand brand manner, marketer - who is master in human-centred communication strategy, designer - who has knowledge about product and user, business analyst - who has knowledge about market trend and forecast and general manager- who have authority to approve action quickly. This team might provide multi-faceted analysis regards current situation to form timely crisis respond. Secondly, prior studies mentioned three reasons of organisational misbehaviour including executive, corporate and spokesperson as crisis causes. From the research, human-centred strategy taps to human value and human-focus in communication. Thus, lack of humancentred concept can embrace three causes founded previously by Greyser (2009), Griffith et al. (2018) and Salvador et al. (2018). Thirdly, market understanding has long been recognized as key success of brand communication and branding. Fully understanding about market including consumer, external environment such as culture might help firms avoid falling to communication trap. Fourthly, innovation is a tremendous component in any organization to flour overseas in Industrial 4.0 age. Under-innovation may reduce level of competitiveness (Roll 2015), blur core competencies (Trott 2008) and lead to the fall of entire brand - taking example of Kodak. Supporting this idea, Roll (2015) innovation is a paramount for competitive advantages and future success of a brand. Fifthly, leadership and management in this context refer to how leader can manage smoothly across functional departments. Consequently, misbehaviour from internal stakeholders could be limited. Finally, lacking of quality assurance is likely to cause brand crisis related to performance, following crisis typology of Coombs (2007).
This trap might lead to: financial loss due to brand trust lost (Bundy et al. 2016), consumers boycott (Braunsberger and Buckler 2011). This problem will be a starting point for crisis spillover on both online and offline platforms. Observing hidden causes, internal drivers, will help managers prioritize actions, simulate option to humanize crisis response strategy following users' preferences.

Despite some mentioned notable findings, this research results are derived from a small sample. In-depth interview experts are mainly from Asian Corporations and key-note speakers are primarily from the UK. Thus, replications of study in larger samples such as cross-country experts are imperative to increase the strength of the results. Additionally, the possibility of sampling upon the findings is a second limitation. A majority of experts is from branding and management background in specific industries; hence, their experiences are drawn upon their individual backgrounds. Hence, future research should adopt in-depth interviews with experts working in communication agencies to improve the validity of the study's findings. This research is primarily adopted qualitative research to explore the key insights of brand crisis; alternative possibilities arise, future scholars might examines those drivers using econometric model to generalise research results.

\section{Acknowledgements}

Authors would like to thank Mrs. Nguyen Thi Tuyet Mai (mai.nguyenthituyet@griffithuni.edu.au), Marketing Specialist at Thuongmai University Hanoi and Mr. Le Nam Long (lenamlong.is.me@gmail.com) - Head of Creative at Shopee Vietnam for their insightful comments.

\section{References}

Aaker DA (2010) Building strong brands. Pocket Books. London.

Anning-Dorson T (2018) Innovation and competitive advantage creation. International Marketing Review 35 (4): 580-600. https://doi.org/10.1108/IMR-11-2015-0262 
Arendt C, LaFleche M, Limperopulos M (2017) A qualitative meta-analysis of apologia, image repair, and crisis communication: Implications for theory and practice. Public Relations Review 43 (3): 517-526. https://doi.org/10.1016/j. pubrev.2017.03.005

Augusto M, Torres P (2018) Effects of brand attitude and eWOM on consumers' willingness to pay in the banking industry: Mediating role of consumer-brand identification and brand equity. Journal of Retailing and Consumer Services 42: 1-10. https://doi.org/10.1016/j.jretconser.2018.01.005

Bilgihan A, Barreda A, Okumus F, Nusair K (2016) Consumer perception of knowledge-sharing in travel-related Online Social networks. Tourism Management 52: 287-296. https://doi. org/10.1016/j.tourman.2015.07.002

Bradley D (2018) How long should brands stay silent on social media after a deadly crisis? https://www.prweek.com/article/1384777/long-brands-stay-silent-social-media-deadlycrisis

Braunsberger K, Buckler B (2011) What motivates consumers to participate in boycotts: Lessons from the ongoing Canadian seafood boycott. Journal of Business Research 64 (1): 96-102. https://doi.org/10.1016/j.jbusres.2009.12.008

Braunsberger K, Buckler B (2011) What motivates consumers to participate in boycotts: Lessons from the ongoing Canadian seafood boycott. Journal of Business Research 64 (1): 96-102. https://doi.org/10.1016/j.jbusres.2009.12.008.

Braunsberger K, Buckler B (2011) What motivates consumers to participate in boycotts: Lessons from the ongoing Canadian seafood boycott. Journal of Business Research 64 (1): 96-102.

Bundy J, Pfarrer MD, Short CE, Coombs WT (2017) Crises and crisis management: Integration, interpretation, and research development. Journal of Management 43 (6): 1661-1692. https://doi.org/10.1177/0149206316680030

Bundy J, Pfarrer MD (2015) A burden of responsibility: The role of social approval at the onset of a crisis. Academy of Management Review 40: 345-369.

Bundy J, Pfarrer M, Short C, Coombs W (2016) Crises and crisis management: integration, interpretation, and research development. Journal of Management 43 (6): 1661-1692.

Chiou J, Hsu AC, Hsieh C (2013) How negative online information affects consumers' brand evaluation: The moderating effects of brand attachment and source credibility. Online Information Review 37 (6): 910-926. https://doi.org/10.1108/ OIR-02-2012-0014

Choi S, Mattila AS (2008) Perceived controllability and service expectations: Influences on customer reactions following service failure. Journal of Business Research 61 (1): 24-30. https://doi.org/10.1016/j.jbusres.2006.05.006

Choi Y, Lin YH (2009) Consumer response to crisis: Exploring the concept to involvement in Mattel product recalls. $\mathrm{Pu}-$ blic Relation Review 35: 18-22. https://doi.org/10.1016/j. pubrev.2008.09.009

Chun R (2016) What holds ethical consumers to a cosmetics brand: The body shop case. Business \& Society 55 (4): 528549. https://doi.org/10.1177/0007650313520201

Claeys A, Cauberghe V (2014) What makes crisis response strategies work? The impact of crisis involvement and message framing. Journal of Business Research 67 (2): 182-189. https:// doi.org/10.1016/j.jbusres.2012.10.005
Cleeren K (2015) Using advertising and price to mitigate losses in a product-harm crisis. Elsevier Inc, Greenwich.

Coombs WT (2007) Protecting organization reputations during a crisis: The development and application of situational crisis communication theory. Corporate Reputation Review 10 (3): 163-176. https://doi.org/10.1057/palgrave.crr.1550049

Coombs WT (2015) Ongoing crisis communication: Planning, managing, and responding (4th ed) Thousand Oaks, CA: Sage.

Coombs W, Holladay S (2009) Further explorations of post-crisis communication: Effects of media and response strategies on perceptions and intentions. Public Relations Review 35 (1): 1-6.

Crane A (2001) Unpacking the ethical product. Journal of Business Ethics 30 (4): 361-373. https://doi.org/10.1023/ A:1010793013027

Dawar N, Lei J (2009) Brand crises: the roles of brand familiarity and crisis relevance in determining the impact on brand evaluations. Journal of Business Research 62: 509-516.

Đỗ NB (2016) Brand crisis repose strategy in Vietnam. Economy and Forecast Review 30: 26-28.

Dutta S, Pullig C (2011) Effectiveness of corporate responses to brand crises: The role of crisis type and response strategies. Journal of Business Research 64 (12): 1281-1287. https://doi. org/10.1016/j.jbusres.2011.01.013

Fan Y (2005) Ethical branding and corporate reputation. Corporate Communications: An International Journal 10 (4): 341-350. https://doi.org/10.1108/13563280510630133

Florea DL (2015) The relationship between branding and diffusion of innovation: A systematic review. Procedia Economics and Finance 23: 1527-1534. https://doi.org/10.1016/S22125671(15)00407-4

Forbes (2018, September 12) Are you ready for your next brand crisis? https://www.forbes.com/sites/forrester/2018/09/12/ are-you-ready-for-your-next-brand-crisis/\#42c3d4932ba7

Foroudi P, Jin Z, Gupta S, Foroudi M, Kitchen P (2018) Perceptional components of brand equity: Configuring the symmetrical and asymmetrical paths to brand loyalty and brand purchase intention. Journal of Business Research, in press, corrected proof. https://doi.org/10.1016/j.jbusres.2018.01.031

Giacomin J (2014) What is human centred design? The Design Journal 17.4 (2014): 606-623. https://doi.org/10.2752/17563 0614X14056185480186

Gibbs G (2007) Analyzing qualitative data (1st ed) London: SAGE Publication Ltd.

Gobé M (2009) Emotional branding: the new paradigm for connecting brands to people. Updat and rev. edn. Allworth Press, New York.

Greyser SA (2009) Corporate brand reputation and brand crisis management. Management Decision 47 (4): 590-602. https:// doi.org/10.1108/00251740910959431

Griffith DA, van Esch P, Trittenbach M (2018) Investigating the mediating effect of Uber's sexual harassment case on its brand: Does it matter? Journal of Retailing and Consumer Services 43: 111-118. https://doi.org/10.1016/j.jretconser.2018.03.007

Hansen N, Kupfer A-K, Hennig-Thurau T (2018) Brand crises in the digital age: The short- and long-term effects of social media firestorms on consumers and brands. International 
Journal of Research in Marketing. https://doi.org/10.1016/j. ijresmar.2018.08.001

Hewett K, Rand W, Rust RT, van Heerde HJ (2016) Brand buzz in the echoverse. Journal of Marketing 80 (3): 1-24. https:// doi.org/10.1509/jm.15.0033

Hsu L, Lawrence B (2016) The role of social media and brand equity during a product recall crisis: A shareholder value perspective. International Journal of Research in Marketing 33 (1): 59-77. https://doi.org/10.1016/j.ijresmar.2015.04.004

Huang R, Sarigöllü E (2012) How brand awareness relates to market outcome, brand equity, and the marketing mix. Journal of Business Research 65 (1): 92-99. https://doi.org/10.1016/j. jbusres.2011.02.003

IDEO (2015) The field guide to human-centered design. San Francisco.

Ip CY, Liang C, Feng JY (2018) Determinants of public attitude towards a social enterprise crisis in the digital era: Lessons learnt from THINX. Public Relations Review. https://doi. org/10.1016/j.pubrev.2018.05.005

Jahng MR, Hong S (2017) How Should You Tweet?: The effect of crisis response voices, strategy, and prior brand attitude in social media crisis communication. Corporate Reputation Review 20 (2): 147-157.

Jahng MR, Hong S (2017) How should you tweet?: The effect of crisis response voices, strategy, and prior brand attitude in social media crisis communication. Corporate Reputation Review 20 (2): 147-157.

Jeon J, Baeck S (2016) What drives consumer's responses to brand crisis? The moderating roles of brand associations and brand-customer relationship strength. Journal of Product \& Brand Management 25 (6): 550-567. https://doi.org/10.1108/ JPBM-10-2014-0725

Jia M, Ruan H, Zhang Z (2017) How rumors fly. Journal of Business Research 72: 33-45. https://doi.org/10.1016/j.jbusres. 2016.11.010

Johar GV, Birk MM, Einwiller SA (2010) How to save your brand in the face of crisis. MIT Sloan Management Review 51 (4): 57-64 https://sloanreview.mit.edu/article/how-to-save-yourbrand-in-the-face-of-crisis/

Kotler P, Armstrong G, Opresnik MO (2018) Principles of marketing (17e) Global. Pearson, Harlow, England.

Kuniavsky M (2003) Observing the user experience. San Francisco, CA: Morgan Kaufmann Publishers.

Labrecque LI, vor dem Esche J, Mathwick C, Novak TP, Hofacker CF (2013) Consumer power: Evolution in the digital age. Journal of Interactive Marketing 27 (4): 257-269. https://doi. org/10.1016/j.intmar.2013.09.002

Larcker D, Tayan B (2018) We studied 38 incidents of CEO bad behavior and measured their consequences. Harvard Business Review https://hbr.org/2016/06/we-studied-38-incidents-ofceo-bad-behavior-and-measured-their-consequences

Laufer D, Garrett TC, Ning B (2017) The moderating role of power distance on the reaction of consumers to the CEO as a spokesperson during a product harm crisis: Insights from China and South Korea. Journal of International Management. https://doi.org/10.1016/j.intman.2017.12.002
López-Cabarcos MÁ, Göttling-Oliveira-Monteiro S, VázquezRodríguez P (2015) Organizational Capabilities and Profitability. SAGE Open 5 (4). https://doi.org/10.1177/ 2158244015616852

Ma L, Zhan M (2016) Effects of attributed responsibility and response strategies on organizational reputation: A meta-analysis of situational crisis communication theory research. Journal of Public Relations Research 28: 102-119. https://doi.org/10. 1080/1062726X.2016.1166367

Mainwaring S (2011) We first. New York: Palgrave Macmillan.

Malone C, Fiske ST (2014) The human brand: how we relate to people, products, and companies (1rst edn). Jossey-Bass, San Francisco.

Marynissen H, Ladkin D, Denyer D, Snoeijers E, Van Achte T (2013) The role of individual risk perception in an organization managing high risks. Conference paper for the third international conference on engaged management scholarship. Lisbon. https://doi.org/10.2139/ssrn.2322816

McKinsey (2012) Building brands in emerging markets. McKinsey Quarterly, 9.

Mills GE (2003) Action research: A guide for the teacher researcher (2nd ed) Upper Saddle River, NJ: Prentice Hall.

Neuman WL, Kreuger L (2003) Social work research methods: qualitative and quantitative approaches. boston, ma: allyn and bacon.

Owyang J (2011) How corporations should prioritize social business budgets (Ebook). Altimerter Group. http://www. socialmediathinklab.com/wp-content/uploads/2012/06/ 4Owyang_Li_Tran_Jones_2011_How-Corporations-ShouldPrioritize-Social-Business-Budgets.pdf

Pang A, Hassan NBBA, Chong ACY (2014) Negotiating crisis in the social media environment: Evolution of crises online, gaining credibility offline. Corporate Communications 19 (1): 96-118. https://doi.org/10.1108/CCIJ-09-2012-0064

Peter JP, Olson JC (2010) Consumer behavior and marketing strategy. New York: McGraw-Hill.

PRweek (2017) http://www.prweek.com/article/1384777/longbrands-stay-silent-social-media-deadly-crisis

Pullig C, Netemeyer RG, Biswas A (2006) Attitude basis, certainty, and challenge alignment: a case of negative brand publicity. Journal Academic Marketing Science 34 (4): 528-543. https:// doi.org/10.1177/0092070306287128

Putnam C, Reiner A, Ryou E, Caputo M, Cheng J, Allen M, Singamaneni R (2016) Human-Centered Design in Practice. Journal of Technical Writing and Communication 46 (4): 446-470. https://doi.org/10.1177/0047281616653491

Rea B, J Wang Y, Stoner J (2014) When a brand caught fire: the role of brand equity in product-harm crisis. Journal of Product \& Brand Management 23 (7): 532-542. https://doi.org/10.1108/ JPBM-01-2014-0477

Rea B, Wang YJ, Stoner J (2014) When a brand caught fire: the role of brand equity in product-harm crisis. Journal of Product \& Brand Management 23 (7): 532-542. https://doi.org/10.1108/ JPBM-01-2014-0477.

Roll M (2015) Asian brand strategy: Building and sustaining strong global brand in Asia. Revised Edition edn. Great Britan: Palgrave Macmillan. 
Salvador AB, Ikeda AA, Crescitelli E (2018) Crisis management and its impact on brand image. Scielo.br. http://www.scielo.br/ pdf/gp/2017nahead/en_0104-530X-gp-0104-530X1668-14.pdf

Silverman D (2016) Qualitative research (4E edn). Los Angeles: SAGE.

Snoeijers E, Poels K (2018) Factors that influence organisational crisis perception from an internal stakeholder's point of view. Public Relations Review 44 (1): 65-74. https://doi. org/10.1016/j.pubrev.2017.12.003

Statista (2018). Global digital population 2019 | Statistic. (n.d.) https://www.statista.com/statistics/617136/digital-populationworldwide/

Thomas J, Harden A (2008) Methods for the thematic synthesis of qualitative research in systematic reviews. BMC Medical Research Methodology 8 (1).

Torrington D, Hall L, Atkinson C (Professor of human resource management), Taylor S (2017) Human resource management (10th ed). Harlow, England: Pearson.

Trott $P$ (2008) Innovation management and new product development. Financial Times/Prentice Hall.

Tyagi R (2006) New product introductions and failures under uncertainty. International Journal of Research in Marketing
23 (2): 199-213. https://doi.org/10.1016/j.ijresmar.2005.12.001

Wang Y (2016) Brand crisis communication through social media. Corporate Communications: An International Journal 21 (1): 56-72. https://doi.org/10.1108/CCIJ-10-2014-0065

Xiao Y, Cauberghe V, Hudders L (2018) Humour as a double-edged sword in response to crises versus rumours: The effectiveness of humorously framed crisis response messages on social media. Journal of Contingencies and Crisis Management 26 (2): 247-260. https://doi.org/10.1111/14685973.12188

Yildirim G (2013) Winning hearts, minds and sales: How marketing communication enters the purchase process in emerging and mature markets. International Journal of Research in Marketing 30 (1): 57-68. https://doi.org/10.1016/j. ijresmar.2012.09.006

Yin RK (2014) Case study research: design and methods (5th edn). Los Angeles: SAGE.

Zou P, Li G (2016) How emerging market investors' value competitors' customer equity: Brand crisis spillover in China. Journal of Business Research 69 (9): 3765-3771. https://doi. org/10.1016/j.jbusres.2015.12.068 


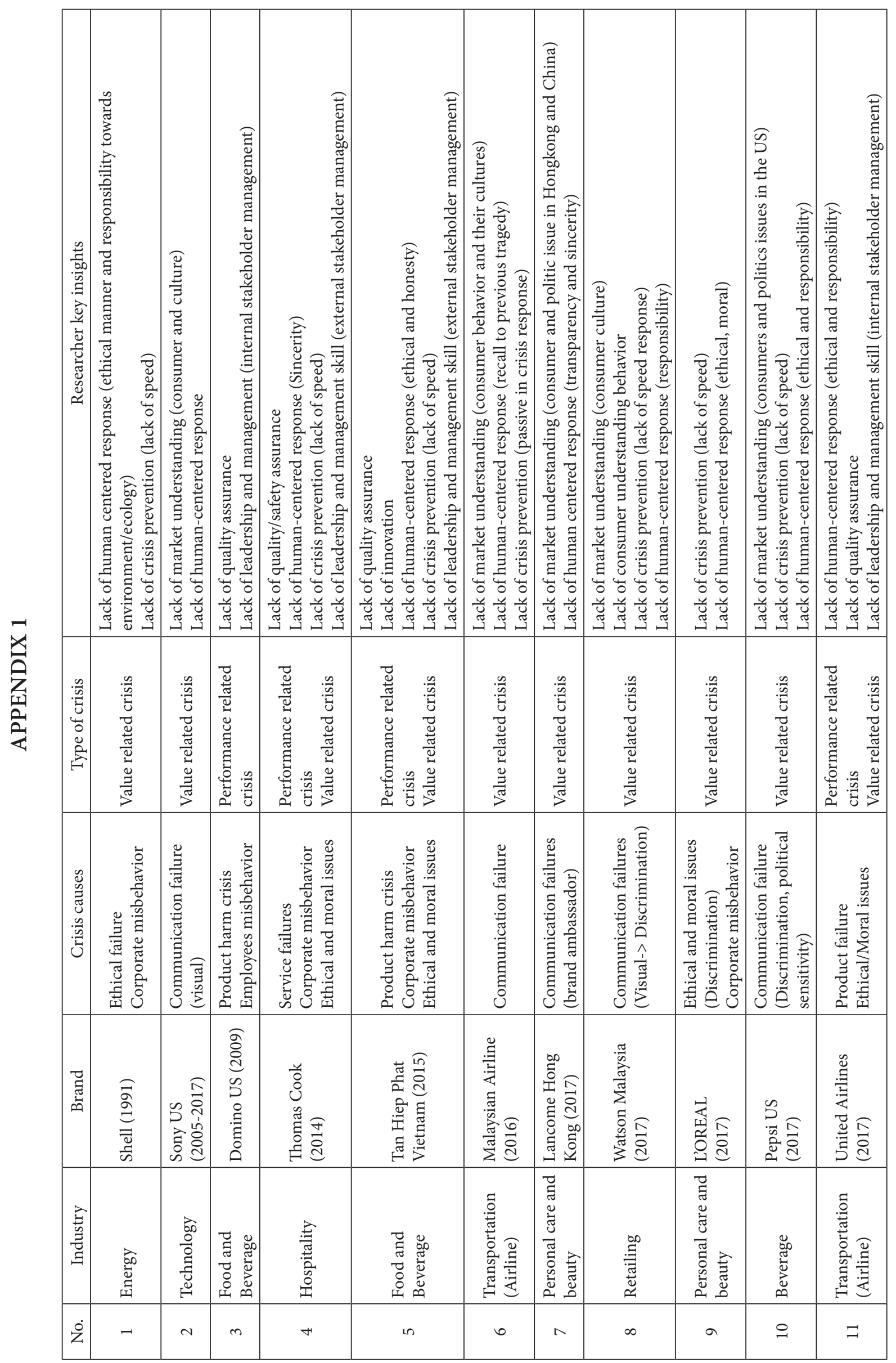




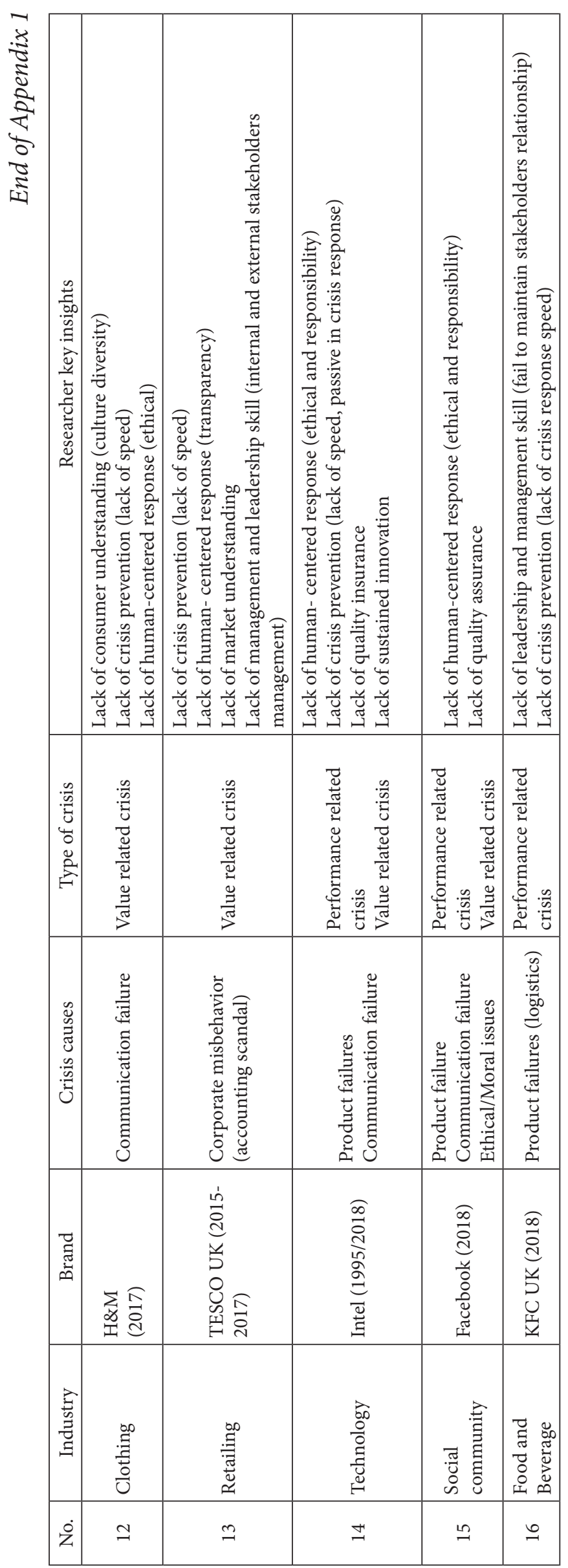




\section{APPENDIX 2}

List of questions - experts interview

\section{Brand and Branding}

1. In your opinion, what is brand and branding?

2. What is/are key elements to build a good brand?

\section{Brand crisis}

3. What is brand crisis? How do we know that our brands are in trouble?

4. Has your brand/ client ever witnessed brand crisis/ reputational troubles before?

If yes, can you describe how this crisis happens and identify causes (external and internal) of that problem.

5. How did your brand response to that crisis?

6. What do you think about this response strategy and how can we improve it?

7. A part from mentioned example, What are other internal causes leading to brand crisis and how is might happened? (Ask experts to explain all mentioned crisis drivers to clarify their opinion)

Note: Those are the key questions are apply for every expert interview, the rest of interview will be flexible according to expert's experience and answers 